Original Research

\title{
Pyocyanine Production, Twitching Motility and Hydrophobicity of Different Wastes on Pseudomonas aeruginosa
}

\author{
Hüseyin Kahraman ${ }^{1 *}$, Cennet Canan Karaderi \\ 'Department of Biology, Faculty of Art and Sciences, Inonu University, Malatya 44280, Turkey \\ ${ }^{2}$ Department of Biology, Institute of Science, Inonu University, Malatya 44280, Turkey
}

Received: 25 February 2020

Accepted: 11 July 2020

\begin{abstract}
Many agricultural and biological waste materials cause environmental problems. To address this, and to achieve economic efficiency (growth, cell surface hydrophobicity (CSH), twitching, biofilm, and pyocyanin production), we used different organic wastes and Pseudomonas aeruginosa (P. aeruginosa). While there is biofilm formation in all organic waste assets, the highest such formation was observed in molasses and waste cheese whey (WCW). Average pyocyanin production in all organic waste except for Nutrient Broth (NB) averaged $3 \mu \mathrm{g} / \mathrm{ml}$. CSH was reached only in the presence of olive waste water (OWW), molasses, and WCW. The highest twitching was achieved by adding WCW at $14 \mathrm{~mm}$. We found no similar studies with $P$. aeruginosa in the literature. We think that this research will result in similar new studies that will reveal methods of handling these waste materials economically thus benefiting the environment.
\end{abstract}

Keywords: organic wastes, $P$. aeruginosa, biofilm, pyocyanine, hidrofobicity, twitching

\section{Introduction}

Contamination of aquatic environments is a serious problem that can cause toxic chemicals to accumulate in food chains and damage flora and fauna. Microbial degradation, or biodegradation, appears to be the most environmentally friendly method of removing hydrocarbons. Other methods can result in toxic compounds entering the environment.

$P$. aeruginosa move with a single, polar, monotric flagellum rotating with proton motivating power. In the

*e-mail: huseyin.kahraman@inonu.edu.tr context of disease, this flagellar swimming motility is important in infection because the lack of swimming ability of the $P$. aeruginosa mutant causes a decrease in pathogenesis in different animals [1, 2].

It is recognized that bacteria growing in biofilms have significant advantages over the independent life forms that we call planktonic. Most bacteria produce biofilms or "microbial cities" that are resistant to conventional antibiotics and counteract mechanical and chemical attack in different environments. In addition, bacteria living in biofilms are more resistant to antibiotics, biocides and other environmental stresses. This close cell-to-cell contact also provides survival advantages by facilitating horizontal gene transfer and the sharing of metabolic by-products in the biofilm [3]. 
Cystic fibrosis in the lungs is a result of this biofilm formation. Biofilms protect bacterial communities. This protection balances the formation of microbial cells on a surface and is a major factor in facilitating the spread of most microbial infections [4].

The genus Pseudomonas can produce a variety of extracellular pigments known as phenazines. A characteristic feature of $P$. aeruginosa is its ability to produce the soluble blue-green pyocyanin pigment from these phenazines. Pyocyanin is involved in the ability of $P$. aeruginosa to produce reactive oxygen species (ROS). Pyocyanin is also capable of binding to organic compounds [5].

Pyocyanin is the most extensively studied of phenazine pigments. Phenazines are classified as secondary metabolites, or compounds that occur during the stationary phase and often have antibiotic properties. Pyocyanin is the secondary metabolite of $P$. aeruginosa [6].

Pyocyanin can also reduce ferric $\left(\mathrm{Fe}^{+3}\right)$ ions to ferrous $\left(\mathrm{Fe}^{+2}\right)$ form, which allows the iron to be removed from the medium to meet the nutritional requirements of $P$. aeruginosa [7].

The hydrophobic property of bacterial surfaces is an important determinant of the adhesion of bacteria to various surfaces and the formation of biofilm by bacteria on living and inanimate surfaces. In particular, the main factors affecting microbial attachment to abiotic surfaces include the properties of the contact surface, cell surface hydrophobicity (CSH) and bacterial mobility capacity. Moreover, bacterial surface components such as fimbria and flagella form $\mathrm{CSH}$ and bacterial mobility, which are closely related to the presence of these determinants for binding [8]. CSH is an important property for the microorganism that affects the activity of various bioprocesses such as cell-cell interaction and the adhesion of bacteria to hydrophobic organic compounds [9]. Experiments show that hydrophobicity is a process that depends on a complex interaction between negative charge, positive charge, and hydrophobic and hydrophilic components on the bacterial surface [10, $11]$.

Type IVa pilus is a protein fiber extending outwards from the cell surface. This structure, which consists of a monomeric subunit called a battery, is responsible for a surface movement known as a twitch. This is also considered an adhesion factor. This phenomenon is recognized as an important virulence factor for $P$. aeruginosa. Surface-bound virulence factors, including the twitching motion of $P$. aeruginosa, biofilm development, and natural defense and contact with target host cell surfaces affect the pathogenicity of $P$. aeruginosa [12].

This study aimed to investigate the presence of $P$. aeruginosa in various organic waste materials focusing on its survival, twitching movement, pyocyanin production, biofilm formation and effect on $\mathrm{CSH}$.

\section{Materials and Methods}

All chemicals were of the highest purity available commercially.

\section{Microorganism}

P. aeruginosa (ATCC 27853), obtained from the ATCC and used this study.

\section{Waste Cheese Whey}

Waste cheese whey (WCW) was collected from commercial cheese factories in Malatya, Turkey.

\section{Waste Frying Oil}

Waste frying oil (WFO) was obtained and collected from the food Restaurant Malatya, Turkey.

\section{Sugar Beet Molasses}

Sugar beet molasses were filtered for removing crude impurities and then, they're autoclaved, and then used.

\section{Other Organic Wastes}

Others have supplied it ourselves because it is household waste (e.g., TCW: Turkish coffee waste (TCW and Tea waste water (TWW).

\section{Growth Conditions}

P. aeruginosa was cultivated in Luria- Bertani (LB) broth medium. Overnight cultures was setting $\mathrm{OD}_{600} \mathrm{~nm}$ of $0,2-0,3$ grown tube and filled with $5 \mathrm{ml}$ in tubes was inoculated and then incubated for $24 \mathrm{~h}$ of time. Phosphate-buffered saline (PBS) and PBS $+10 \%$ different organic wastes. These cultures were subsequently incubated on $37^{\circ} \mathrm{C}$ for $24 \mathrm{~h}$. Bacterial growth was determined by measuring the absorbance at $600 \mathrm{~nm}\left(\mathrm{OD}_{600}\right)$ by a spectrophotometer.

\section{Biofilm Formation}

The cultures were $24 \mathrm{~h}$ and $37^{\circ} \mathrm{C} \mathrm{O} / \mathrm{N}$ incubation. Biofilm formation was determined using a modified method crystal violet assay. Biofilm mass was finally determined as a function of the concentration of this dye based on the absorbance at $570 \mathrm{~nm}$ [13-16].

\section{Pyocyanin Quantitation Assay}

The pyocyanin assay is based on the absorbance of pyocyanin at $\mathrm{OD}_{520} \mathrm{~nm}$ in acidic solution. The absorbance of this solution was measured at $520 \mathrm{~nm}$. Concentrations, expressed as micrograms of pyocyanin produced per milliliter of culture supernatant, were 
determined by multiplying the optical density at $520 \mathrm{~nm}$ by $17.072[17,18]$.

\section{Determination of Hydrophobicity (CSH)}

For cell surface hydrophobicity assay was determined using a modified method. The aqueous phase absorbance was examined at $590 \mathrm{~nm}$. The percentage of cell surface hydrophobicity was determined using the formula, cell surface hydrophobicity $(\%)=($ Initial cell density-final cell density)/initial cell density $\times 100[8$, 19-24].

\section{Twitching Assay}

Plates were inoculated by stabbing an isolated colony grown on overnight LB plates $(2 \%(\mathrm{w} / \mathrm{v})$ agar) onto the Petri dish. Plates were incubated at $37^{\circ} \mathrm{C}$ for 24 hours, and diameter measurements were recorded [25-28]. Plates were photographed with Nicon Coolpix L320.

\section{Results and Discussion}

The main objective was to evaluate organic residues and their potential as media and to investigate the viability of some parameters $\left(\mathrm{OD}_{600}\right.$, biofilm, pyocyanin $\mathrm{CSH}$ production and twitching). NB was used for $(+)$ control and PBS for (-) control. All study results were obtained after 24 hours.

Contrary to expectations, the highest value was reached in the presence of molasses with $\mathrm{OD}_{600} 1.36$. As expected, the lowest was reached in PBS with $\mathrm{OD}_{600}$ 0.038 . The second highest value was $\mathrm{OD}_{600} 0.223$ in the presence of WCW. Taking the PBS medium as control, $\mathrm{OD}_{600}$ increases were observed up to 36-fold with the addition of molasses. $\mathrm{OD}_{600} 0.066$ was reached in the $(+)$ control NB medium, 17-times higher than the control. $\mathrm{OD}_{600}$ remained below $\mathrm{OD}_{600} 0.1$ in the presence of other organic residues except for WCW and molasses (Fig. 1).

When biofilm formation was examined, the highest value was reached in the presence of molasses with $\mathrm{OD}_{570}$ 3.657. The lowest value was in the presence

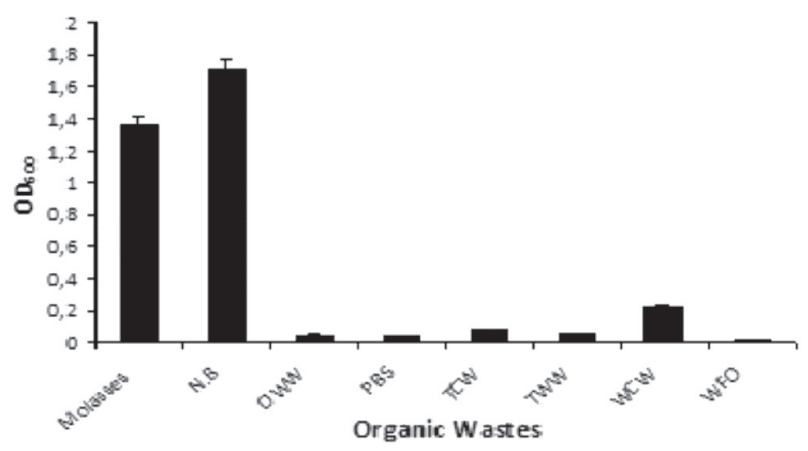

Fig. $1 . \mathrm{OD}_{600}$ values of $P$. aeruginosa at $37^{\circ} \mathrm{C}$ for $24 \mathrm{~h}$.

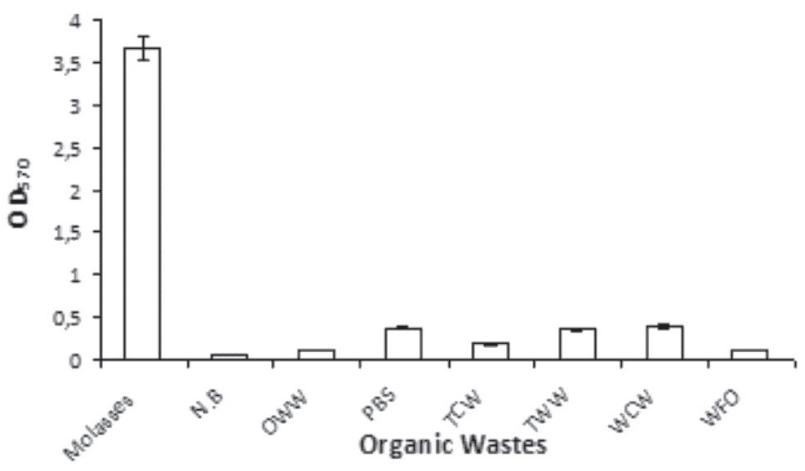

Fig. 2. Biofilm formation by P. aeruginosa at $37^{\circ} \mathrm{C}$ for $24 \mathrm{~h}$.

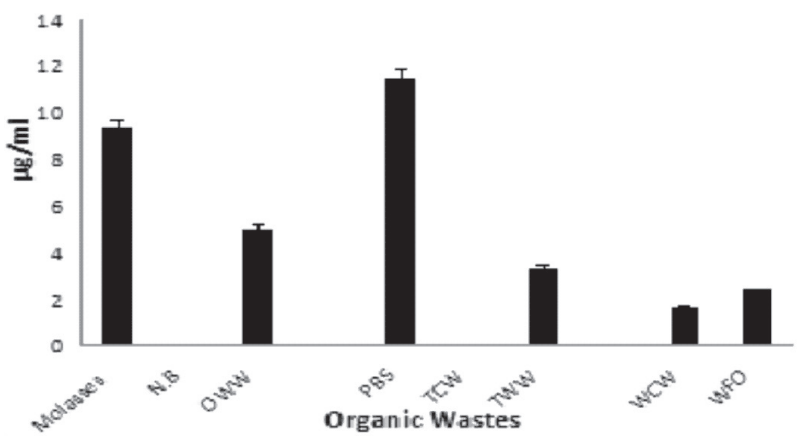

Fig. 3. Pyocyanine production by P. aeruginosa at $37^{\circ} \mathrm{C}$ for $24 \mathrm{~h}$.

of OWW with $\mathrm{OD}_{570}$ 0.106. That is, values below (-) control were obtained. In the presence of molasses, a value of about 9-times above (-) control was obtained. When all the organic waste materials were evaluated, it can be said that they all contributed to formation since values greater than $\mathrm{OD}_{570} 0.1$ were obtained (Fig. 2).

No pyocyanin production was observed in $(+)$ control NB. On the other hand, the highest value was $11.42 \mu \mathrm{g} / \mathrm{ml}$ in the PBS medium (-) control. The next highest was reached in the presence of molasses at $9.36 \mu \mathrm{g} / \mathrm{ml}$. The lowest value was $1.62 \mu \mathrm{g} / \mathrm{ml}$ in the presence of protein-rich WCW. Pyocyanin production in the presence of all organic waste except for NB averaged $3 \mu \mathrm{g} / \mathrm{ml}$ (Fig. 3).

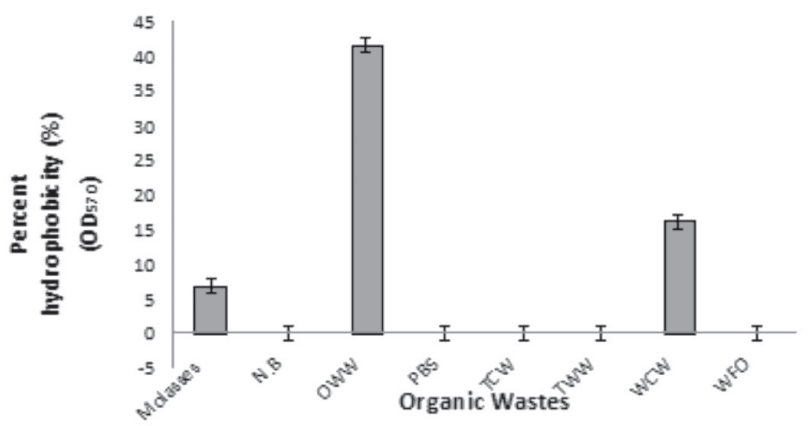

Fig. 4. Percentage of the hydrophobicity of different organic wastes after $24 \mathrm{~h}$. 


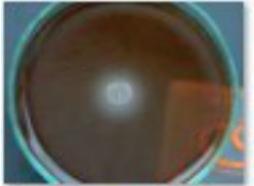

Molasses

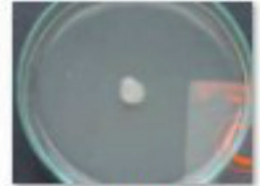

N.B

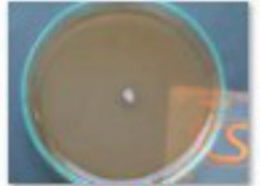

OWW

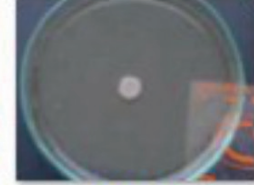

TWW

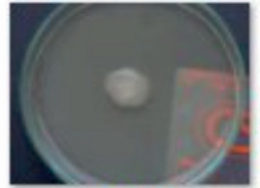

WCW

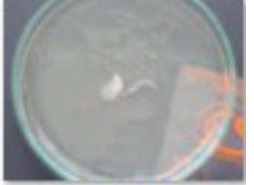

WFO

Fig. 5. Twitching movement on Agar plates.

This was a very difficult study. CSH was reached only in the presence of OWW, molasses, and WCW. No activity was observed in the other organic assets. The highest value was obtained by adding OWW at $41.51 \%$ and the lowest with molasses at $6.8 \%$. However, it is also necessary to have oil in the environment (Fig. 4).

The highest twitching was achieved by adding WCW at $14 \mathrm{~mm}$, while the least shaking movement was observed by adding OWW at $2.67 \mathrm{~mm}$. Although the other media remained below the $9 \mathrm{~mm}$ of the $(+)$ control NB medium, they reached a mean value of $7 \mathrm{~mm}$, which is significant (Fig. 5-6).

While there is biofilm formation in all organic waste assets, the highest such formation was observed in molasses and WCW. In these centers, carbohydrate and protein loads are high. Therefore, molasses and WCW contribute to biofilm formation more than other organic waste-containing environments.

Pyocyanin alone was used as the $(+)$ control of the NB medium. The highest pyocyanin production outside the controls was seen in the presence of molasses and OWW. Oil load in the environment reduces production. Interestingly, however, a decrease was observed in other organic waste assets compared to the (-) control PBS medium. It is not possible to comment on the decrease in this study because the reason is not fully understood. Pyocyanin is involved in the ability of P. aeruginosa to produce reactive oxygen species (ROS). Pyocyanin is also capable of binding to organic compounds [5]. This is very important in the destruction of organic matter.

Hydrophobicity of more than $40 \%$ was observed after the addition of OWW with the highest oil and carbohydrate load. In second place, it was $16 \%$ in the

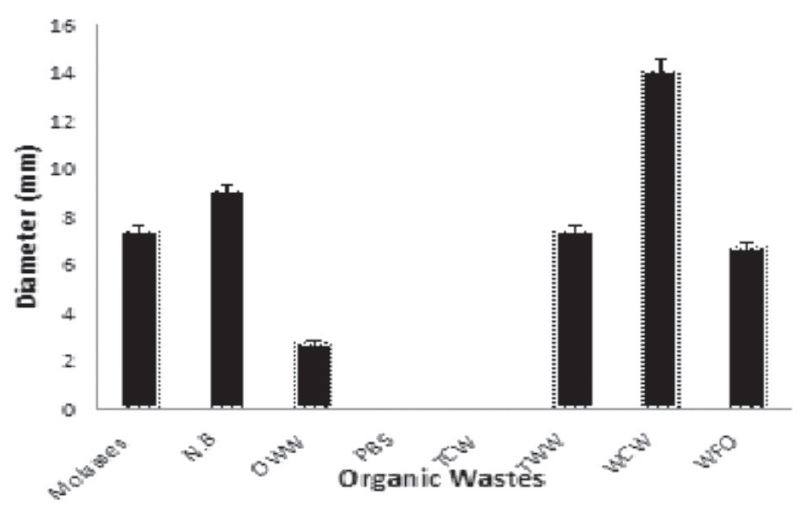

Fig. 6. Twitching motility. Graphical representation of movement at $37^{\circ} \mathrm{C}$ for $24 \mathrm{~h}$. presence of WCW, which also had a high fat load. Molasses, which had a relatively low carbohydrate load, was $6.8 \%$. Although the oil load was high, we believe that no value can be obtained in the presence of WFO without another $\mathrm{C}$ source. No significant $\mathrm{OD}_{600}$ value could be seen. The presence of fat alone in $\mathrm{CSH}$ production does not make sense since the energy source should also be present in the environment.

As for twitching, when compared with the control, only a 1.6-fold increase with an increased protein load in the presence of WCW could be observed. In the presence of other organic wastes, negative impacts below $9 \mathrm{~mm}$ were observed.

\section{Conclusion}

After biological work with synthetic chemicals, this synthetic substance is released to the environment. As a result, environmental pollution occurs and it takes years to clean. With this study, we wanted to show that many microbiological studies can also be carried out with organic wastes and as a result, meaningful data can be obtained. The work we do here is not a microbial degradation study. We did not take these wastes and processed them as such, except sterilization. We used both domestic and industrial organic waste as waste. We did not calculate the amount of organic matter at the beginning and after the experiment. Our aim is to produce and show the secondary metabolites produced by $P$. aeruginosa using organic wastes. It is aimed to produce secondary metabolites, both environmentally and economically.

Organic wastes were used for the first time in secondary metabolite production. We think that this study will lead to similar new studies. At the same time, we think that the way to bring these wastes into the economy will be opened and the environment will be protected. We think that this research will result in similar new studies that will reveal methods of handling these waste materials economically thus benefiting the environment. We believe it is one of the first articles investigating the effect of organic wastes on bacterial metabolites.

\section{Conflict of Interest}

The authors declare no conflict of interest. 


\section{References}

1. LOVEWELL R.R., HAYES S.M., O'TOOLE G.A., BERWIN B. Pseudomonas aeruginosa flagellar motility activates the phagocyte PI3K/Akt pathway to induce phagocytic engulfment. Am. J. Physiol. Lung Cell Mol. Physiol. 306, 698, 2014.

2. MURRAY T.S., KAZMIERCZAK B.I. FlhF Is Required for swimming and swarming in Pseudomonas aeruginosa. J. Bacteriol. 188 (19), 6995, 2006.

3. BAUMGARTEN T., SPERLING S., SEIFERT J., BERGEN M., VON, STEINIGER F., WICK L.Y., HEIPIEPER H.J. Membrane vesicle formation as a multiple-stress response mechanism enhances Pseudomonas putida DOT-T1E cell surface hydrophobicity and biofilm formation. Appl. Environ. Microbiol. 78 (17), 6217, 2012.

4. ZENG G., VAD B.S., DUEHOLM M.S., CHRISTIANSEN G., NILSSON M., TOLKER-NIELSEN T., NIELSEN P.H., MEYER R., OTZEN D.E. Functional bacterial amyloid increases Pseudomonas biofilm hydrophobicity and stiffness. Front. Microbiol. 6 (1099), 1, 2015.

5. EL-FOULY M.Z, SHARAF A.M., SHAHIN A.A.M., EL-BIALY H.A., OMARA A.M.A. Biosynthesis of pyocyanin pigment by Pseudomonas aeruginosa. J. Radiat. Res. Appl. Sci. 8, 36, 2015.

6. NOTO M.J., BURNS W.J., BEAVERS W.N., SKAAR E.P. Mechanisms of pyocyanin toxicity and genetic determinants of resistance in Staphylococcus aureus. J. Bacteriol. 199 (17), 171, 2017.

7. MULLER M., MERRETT N.D. Pyocyanin production by Pseudomonas aeruginosa confers resistance to ionic silver. Antimicrob Agents Chem 58 (9), 5492, 2014.

8. ROSSI C., CHAVES-LOPEZ C., SERIO A., ANNIBALLI F., VALBONETTI L., PAPARELLA A. Effect of origanum vulgare essential oil on biofilm formation and motility capacity of Pseudomonas fluorescens strains isolated from discoloured Mozzarella cheese. J. Appl. Microbiol. 124, 1220, 2018.

9. LIU Y., MA X., ZENG G., ZHONG H., LIU Z., JIANG Y., YUAN X., HE X., LAI M., HE Y. Role of low-concentration monorhamnolipid in cell surface hydrophobicity of Pseudomonas aeruginosa: adsorption or lipopolysaccharide content variation. Appl. Microbiol. Biotechnol. 98, 10231, 2014.

10. COURTNEY H.S., OFEK I., PENFOUND T., NIZET V., PENCE M.A, KREIKEMEYER B., PODBIELBSKI A., HASTY D.L., DALE J.B. Relationship between expression of the family of $\mathrm{m}$ proteins and lipoteichoic acid to hydrophobicity and biofilm formation in Streptococcus pyogenes. Plos One 4 (1), 1, 2009.

11. ZHONG H., ZENG, G.M., LIU J.X, Xu X.M., YUAN X.Z., FU H.Y. Huang G.H., Liu Z.F., Ding Y., Adsorption of monorhamnolipid and dirhamnolipid on two Pseudomonas aeruginosa strains and the effect on cell surface hydrophobicity. Appl. Microbiol. Biotechnol. 79, 671, 2008.

12. ALLISON T.M., CONRAD S., CASTRIC P. The group I pilin glycan affects type IVa pilus hydrophobicity and twitching motility in Pseudomonas aeruginosa 1244. Microbiol. 161, 1780, 2015.

13. ADAMUS-BIALEK W., KUBIAK A. CZERWONKA G. Analysis of uropathogenic Escherichia coli biofilm formation under different growth conditions. ACTA Biochim. Pol. 62 (4), 765, 2015.

14. CRESPO A., PEDRAZ L., ASTOLA J., TORRENTS E. Pseudomonas aeruginosa exhibits deficient biofilm formation in the absence of class II and III ribonucleotide reductases due to hindered anaerobic growth. Front. Microbiol. 7 (688), 1, 2016.

15. KIM H., PARK H. Ginger extract inhibits biofilm formation by Pseudomonas aeruginosa PA14. Plos One 8 (9), 1, 2013.

16. WU C., CHENG Y., YIN H., SONG X., LI W., ZHOU X., ZHAO L., TIAN L., HAN J., YU H. Oxygen promotes biofilm formation of Shewanella putrefaciens CN32 through a diguanylate cyclase and an adhesin. Nat. Sci. Rep. 3 (1945), 1, 2013.

17. SCHABER J.A., CORTY N.L, MCDONALD N.A., GRAHAM E.D., CHELUVAPPA R., GRISWOLD J.A., HAMOOD A.N. Analysis of quorum sensing-deficient clinical isolates of Pseudomonas aeruginosa. J. Med. Microbiol. 53 (9), 841, 2004.

18. RA'OOF W.M., LATIF I.A.R. In vitro study of the swarming phenomena and antimicrobial activity of pyocyanin produced by Pseudomonas aeruginosa isolated from different human infections. Europ. J. Sci. Res. 47, 405, 2010.

19. SUBHASWARAJA P., BARIKA S., MACHAB C., CHIRANJEEVIB P.V., SIDDHARDHA B., Anti quorum sensing and anti biofilm efficacy of cinnamaldehyde encapsulated chitosan nanoparticles against Pseudomonas aeruginosa PAO1. LWT Food Sci. Technol. 97, 752, 2018.

20. TRIBEDI P., SIL A.K. Cell surface hydrophobicity: a key component in the degradation of polyethylene succinate by Pseudomonas sp. AKS2. J. Appl. Microbiol. 116, 295, 2013.

21. YALCIN E., CAVUSOGLU K., OZEN E. Hydrocarbon degradation by a new Pseudomonas sp., strain RW-II, with polycationic surfactant to modify the cell hydrophobicity. Environ. Technol. 32 (15), 1743, 2011.

22. ABBASNEZHAD H., GRAY M.R., FOGHT J.M. Two different mechanisms for adhesion of Gram-negative bacterium, Pseudomonas fluorescens LP6a, to an oil-water interface. Coll Surf B: Biointerfaces. 62, 36, 2008.

23. KANNAN S., SATHASIVAM G., MARUDHAMUTHU M. Decrease of growth, biofilm and secreted virulence in opportunistic nosocomial Pseudomonas aeruginosa ATCC 25619 by glycyrrhetinic acid. Microb. Pathogen. 126, 332, 2019.

24. DOGAN S., GOKALSIN B., ŞENKARDEŞ İ., DOĞAN A., SESAL N.C. Anti-quorum sensing and anti-biofilm activities of Hypericum perforatum extracts against Pseudomonas aeruginosa. J. Ethnopharmacol. 235, 293, 2019.

25. CHOW S., GU K., JIANG L., NASSOUR A., Salicylic acid affects swimming, twitching and swarming motility in Pseudomonas aeruginosa, resulting in decreased biofilm formation. J. Exp. Microbiol. Immunol. 15, 22, 2011.

26. DEIZEL E., COMEAU Y., VILLEMUR R. Initiation of biofilm formation by Pseudomonas aeruginosa 57RP correlates with emergence of hyperpiliated and highly adherent phenotypic variants deficient in swimming, swarming, and twitching motilities. J. Bacteriol. 183 (4), 1195, 2001.

27. GOH S.N. Effects of different amino acids on biofilm growth, swimming motility and twitching motility in Escherichia coli BL21. J. Biol. Life Sci. 4 (2), 104, 2013.

28. SHE P., WANG Y., LUO Z., CHEN L., TAN R., WANG Y., WU Y. Meloxicam inhibits biofilm formation and enhances antimicrobial agents efficacy by Pseudomonas aeruginosa. Microbiol. Open 2018, 7, e545, 1, 2017. 